\title{
Inventing and Mobilising the Local / Inventer et mobiliser le local
}

Sten Hagberg

\section{OpenEdition}

1 Journals

Electronic version

URL: http://journals.openedition.org/apad/4059

DOI: 10.4000/apad.4059

ISSN: 1950-6929

Publisher

LIT Verlag

\section{Printed version}

Date of publication: 1 December 2010

Number of pages: 1-2

ISBN: 978-3-643-10535-6

\section{Electronic reference}

Sten Hagberg, «Inventing and Mobilising the Local / Inventer et mobiliser le local », Bulletin de l'APAD [Online], 31-32 | 2010, Online since 26 July 2010, connection on 21 September 2020. URL : http:// journals.openedition.org/apad/4059; DOI : https://doi.org/10.4000/apad.4059

This text was automatically generated on 21 September 2020 .

Bulletin de l'APAD 


\title{
Inventing and Mobilising the Local / Inventer et mobiliser le local
}

\author{
Sten Hagberg
}

1 When considering the task to edit an APAD-Bulletin on decentralisation and citizen participation, I initially hesitated. What new could be said about decentralisation after the series of APAD-publications touching on the issue over the last 10-15 years? Yet after some further thought, I soon realised that it could be both timely and appropriate to take a fresh look at decentralisation practices carried out across West Africa. The main reason is that initial attempts to decentralise and sometimes also to obstruct policy implementation starting in the 1990s have now given way to years of everyday decentralisation practices, that is, a series of political, economic and cultural practices carried out 'in the name of' decentralisation. Another reason to revisit decentralisation would be to include scholars of various disciplines (political science, human geography and anthropology) to address the issues at stake.

2 The articles of this APAD-Bulletin revisit decentralisation and citizen participation, so as to explore processes currently at work in West Africa, but, as we shall see, differently articulated in various countries, sectors and contexts. All authors are concerned with how the local is mobilised when decentralisation is appropriated by local actors. By doing this these authors also touch upon the invention of the local; in order to be decentralised the local must be invented in the first place! The theme of Inventing and mobilising the local highlights the core stakes and fundamental contradictions of decentralisation practices in West Africa by exploring party politics, water provision, schooling, territorial division, and cultural understanding. The detailed historical contextualisation of current practices runs through all articles, thereby providing thick descriptions of continuity and change. In addition to the five thematic articles presented in this APAD-Bulletin, the French version of Thomas Bierschenk's Key Note Address to the APAD Conference 13-15 December 2007 on Development, Liberalism, and Modernity: Trajectories of an Anthropology of Social Change in Tervuren/Brussels and Louvain-la-Neuve, Belgium, is also included. Bierschenk offers a very insightful and far- 
reaching overview of anthropology and development, and calls for the historicising and localising of approaches.

3 The editorial process has been greatly facilitated by the Department of Cultural Anthropology \& Ethnology at Uppsala University. The language correction was done by Eren Zink (English) and Florence Naud (French), which is gratefully acknowledged. 